\title{
LLOYD GEORGE AND THE DEVELOPMENT OF THE BRITISH GOVERNMENT'S STRIKEBREAKING ORGANIZATION
}

With the release of the Cabinet Papers for the Lloyd George post-war coalition government and the opening of the Lloyd George papers in the Beaverbrook Library, the basis for a reinterpretation of the man and his era was made possible. And, indeed, several studies have been published already, most notably, by Americans. ${ }^{1}$ The thrust of these new works is to make a more sympathetic character of Lloyd George. Thus, Susan Armitage tells us, had he only not been so busy at peace conferences, Lloyd George would have seen to it that the labor disputes of the post-war years were less disruptive, that the grievances of the trade unions were given due consideration, and that more of the promises of the post-war Reconstruction Committee were realized. In the latter, she follows the lead of Paul Johnson, who was one of the first to plow the murky waters of the Public Records Office's offerings. Pointing a heavily accusing finger at Austen Chamberlain and the Treasury for withholding their blessing on "homes fit for heroes" and other Reconstruction plans, Johnson asks whether "an honest effort" might have "headed off the militant strike activity" that denied Lloyd George's reconstruction plans the means of success. ${ }^{2}$ Thus Lloyd George appears as the victim of circumstances beyond his control - a paragon of pragmatic rationality who is opposed by reactionary Cabinet Ministers and bedevilled by stubborn trade-union leaders who refuse to understand why the promised paradise is not forthcoming.

The trouble with the picture of Lloyd George painted above is that it depends too heavily on rationalizations left behind in his papers and those of the members of his Cabinet, combined with memoranda from

1 Of these the most important are: Paul Johnson, Land Fit for Heroes (Chicago, 1968), Susan M. H. Armitage, The Politics of Decontrol: Britain and the United States (London, 1969), and Bentley B. Gilbert, British Social Policy, 1914-1939 (London, 1970). A mixed bag of essays on Lloyd George has been put together by A. J. P. Taylor, Lloyd George (London, 1970). See also Peter Cline, "Reopening the Case of the Lloyd George Coalition", in: Journal of British Studies, X (1970).

Johnson, p. 56. 
the official papers. If, instead, one considers his actions as revealed in some of those same papers, a quite different picture emerges: one that corresponds more closely to the intuitions of G. D. H. Cole, R. H. Tawney, and W. S. Adams. These earlier historians all were unwilling to let Lloyd George's public display of regret about the necessity for him to budget both his time and the public's money interfere with their judgment that he had missed a great opportunity to significantly alter the British way of life in favor of those who had received so little in the past. They charged that by 1919 Lloyd George had lost his prewar taste for radical change, and lived only to retain power. ${ }^{1}$

The recently released papers not only tend to justify this charge but give evidence that they did not carry their intuitions far enough, for under Lloyd George the government would create the policies and organizations that would not only crush the momentum of postwar labor militance but would set the stage for the trade unions' disastrous route in the 1926 General Strike. The papers also testify to a new inhumanity which pervaded the post-war government's approach to labor problems and which earlier critics tended to blame on Conservative influence or economic necessity and missed Lloyd George's personal responsibility.

Consider, for example, what Cole or Tawney could have done with the now established fact that Lloyd George was himself the foremost advocate of the use of wartime food controls to starve striking railwaymen and miners back to work. This one revelation switches the original charge of insincerity to inhumanity. ${ }^{2}$ It shows that Lloyd George had become a man who equated challenge with treason, and would fight the enemy at home as he fought the one abroad - with no holds barred. While it is true that he was away during a good deal of the labor strife that took place in 1919 , there is no reason to believe that, had he been at home, the direction of events would have taken a more conciliatory turn. In fact, if his activities on his periodic returns to London are any indication, they would lead us to believe that the

1 This older view of Lloyd George portrayed him as a man who would yield matters of principle for political gain, and as a politician who missed his chance for greatness by failing to implement the recommendations of his own Reconstruction Committee. Cf. G. D. H. Cole and Raymond Postgate, The British Common People, University Paperback Edition (New York, 1947), pp. 543-67; R. H. Tawney, "The Abolition of Economic Controls", in: Economic History Review, First Series, XIII, pp. 1-30; W. S. Adams, "Lloyd George and the Labour Movement", in: Past \& Present, No 3 (1953).

2 Both Armitage and Johnson document Lloyd George's plans to use food control as weapon against the unions, but neither seem particularly impressed by this behavior on the part of a man who claimed to be a friend of the worker. See especially Armitage, pp. 15-36. 
intensity of the hostility would have been heightened. It was not that Lloyd George was motivated by fear of revolution, as were, for example, Peter Shortt and Robert Horne. Nor was he a perennial warrior like Churchill. He was much too intelligent for either of those roles. As Thomas Jones has told us, there was a tonque-in-cheek quality to Lloyd George's approach to domestic Bolshevism. He could on occasion use the rhetoric of the "red scare", as when he referred to the danger of workers establishing a "Soviet Republic", or to a mysterious "small but active body of men" working to subvert organized labor, but these phrases were used to "win over public opinion", as he admitted in a letter to Bonar Law. ${ }^{1}$ Years of war had left Lloyd George with one primary goal - to be done with unrest at home and abroad - and he was not overly concerned with the means used to obtain that end.

To aid him in his evaluation of the intent of the British worker, Lloyd George had more extensive reports available to him than any Prime Minister in British history. These studies, carried out under the direction of the Industrial Unrest Commission of Enquiry, 1917-18, had blamed unrest on inflationary prices and low wages, and concluded that the British worker was basically loyal and uncorrupted by revolutionary ideas. ${ }^{2}$ As Tom Jones had advised him, echoing the recommendations of the Commission, "Bolshevik propaganda is only dangerous in so far as it can lodge itself in the soil of real grievances". ${ }^{3}$ Hence, Jones suggested, the government should push ahead with a program of advanced social measures to ameliorate the workers' lives. Unfortunately, such a program was rapidly becoming, as the year 1919 progressed, both politically and fiscally impossible.

With Austen Chamberlain keeping a firmly negative watch on any measures that might threaten his attempts to balance the budget, Lloyd George could not even get an extensive social program out of his own Cabinet. Chamberlain had a simple, old-fashioned view of his job as Chancellor of the Exchequer. He spoke of it as similar to that of a gardener since both occupations were "at the mercy of elemental forces". Chamberlain was guided by the description of these "forces" in the report of the Cunliffe Committee of 1918, which called for a balanced budget, a return to the gold standard and a post-war policy

1 Thomas Jones, Whitehall Diary, ed. by Keith Middlemas, I (London, 1969), p. 97; Lloyd George to Tom Jones, March 17, 1919, Lloyd George Papers F/23/4/36, Beaverbrook Library, London; The Times, September 29, 1919.

2 Reports of the Commission of Enquiry into Industrial Unrest [Cd 8662-8669] (1917-18), XV, passim.

3 Thomas Jones to Lloyd George, February 8, 1919, quoted in Jones, p. 73.

- Quoted in Armitage, p. 15. 
of deflation designed to restore Britain's competitive position in world trade. In the immediate aftermath of the Armistice, Chamberlain was temporarily outvoted in Cabinet decisions relating to Reconstruction matters, which were seen to take precedence over fiscal problems. But as the post-war inflation soared and British exports became increasingly overpriced, Chamberlain's position grew stronger until in August of 1919 his views were accepted and the government became officially committed to deflation and decontrol. ${ }^{1}$

Thus, having no power to produce a feasible carrot, Lloyd George was seemingly left with two options; resign or prepare the stick with which to beat back the industrial unrest which was sure to follow attempts to hold back wages and reorganization schemes that both the miners and the railwaymen felt entitled to. Actually these potentially dangerous antagonists were not as much of a threat to Lloyd George as has been commonly assumed, and that perhaps explains why resignation was never seriously considered by him. Lloyd George's confidence was based on the knowledge that the government had already been developing an organization to handle industrial emergencies since early in 1919 and thus he had merely to strengthen it to meet any new threat.

At a meeting of the War Cabinet on February 4th, 1919 the basis was laid. The meeting had been called to discuss a strike by the London Underground Railwaymen and a threatened strike by the electrical engineers, which would have added darkness as a further impediment to mobility. After an initial proposal from Winston Churchill that the military be used to crush the strikes, Lord Curzon came up with a more inspired idea. He suggested a permanent committee be formed to take over the detailed problems of industrial strife. The Cabinet would then be free to handle matters of policy. The new organization would be modeled on the Committee of Imperial Defense and other interdepartmental organizations that had been set up during the war. It was to be called the Industrial Unrest Committee and was instructed to make all "Necessary arrangements" for dealing with situations caused by strikes. ${ }^{2}$ Among its members were the Minister of Labour,

1 Ibid., p. 15. A recent economic survey of the period claims that the budget of 1920 was the "first attack on inflation". While true in a fiscal sense certainly the "first attack" on inflation was the effort launched to meet the threat of strikes and prevent major wage increases. Cf. Derek H. Aldcroft, The Inter-war Economy: Britain, 1919-1939 (London, 1970), p. 303.

2 Cabinet Papers (henceforth Cab) 23/9, War Cabinet 525, and 27/59 UC Series, Industrial Unrest Committee, Minutes and Proceedings (this committee should not be confused with the Commission of Enquiry cited p. 3, note 2), Public Records Office, London. 
the President of the Board of Trade, the Secretary for Scotland, the First Lord of the Admiralty, the Secretary for Home Affairs, the Secretary of War. ${ }^{1}$ Subcommittees were appointed to arrange for governmental provision of the "necessities of life" during emergencies e.g., Transportation, Communication, Utilities, etc. ${ }^{2}$

At its first meeting, the Industrial Unrest Committee (IUC) exhibited the militaristic nature of its origins and of its membership, which was to characterize its approach to strikes throughout its existence. Shortly after the Cabinet meeting on February 4th the IUC gathered to discuss the tube strike. It decided to use 1,000 lorries and 200 vans to be provided along with the necessary drivers by the army as the basis of two supplementary transport services for the duration of the strike. ${ }^{3}$

Later on the same day, the Cabinet met again to formulate a public statement about the strike and the actions the government was taking. The draft statement proposed by Peter Shortt, the Home Secretary, was a classic example of the "red scare" technique of justifying government activities. It claimed that the recent strikes "were not bona fide strikes, but a Bolshevik attack upon the whole public, and therefore the government was taking steps to meet the situation". The use of the army was in this situation not to be regarded as "strikebreaking" but a public service. When it finally went to the press the "Bolshevik attack" had been modified to "small sections of men which aim at inflicting much distress upon the community", a phrase that would appear later in the speeches of Lloyd George. ${ }^{4}$

While the government was occupied with the tube workers, there were more ominous developments amongst the unions of the Triple Alliance: the railwaymen, the miners and the dockworkers. Lloyd George returned from Paris to take a personal look at the looming crisis. On February 7th, he warned the Cabinet that the Triple Alliance would "hold up the community" and might even prevent the distribution of food. Therefore, for the first time, he "seriously suggested the withholding of food from the strikers" as a means of breaking

1 Respectively, Stanley, Munro, Long, Home, Shortt, and Churchill.

${ }^{2} \mathrm{Cab} 27 / 59$. Subcommittees also were interdepartmental in nature and tended at first to proliferate. This feature was revised later, first by Eric Geddes and then more radically by John Anderson.

${ }^{3}$ Cab 27/59, meetings No 1, February 4, 1919, No 4, February 6, and No 6, February 8.

$4 \mathrm{Cab} 23 / 10$, War Cabinet 526, February 4, 1919. Tom Jones, the Cabinet Secretary, was somewhat amused by these discussions and wrote a report of them in his diary, which wondered "whether or not Curzon and Long have ever been in a Tube and am thinking of referring the question to the Ministry of Research". Jones, p. 75. 
strikes. On February 10th, after further deliberation, he directed the IUC to investigate the possibilities of conserving available coal and developing substitute fuels. In addition, he ordered protection for food depots and suggested the possible use of naval and general reserves in an emergency. ${ }^{1}$ The IUC, meeting on the same day, discussed these proposals from the Prime Minister along with others, and decided to act on the following: arrange for port protection, map all available food stocks, and set up priorities on the use and export of coal. ${ }^{2}$

Meanwhile, Robert Horne, the Minister of Labour, was engaged in negotiations with representatives of the miners' union. While the miners overwhelmingly had rejected the government's wage offer, they did agree to put off their strike until a royal commission under Lord Sankey delivered its interim report. ${ }^{3}$ This was the first of what were to be costly delays for the miners. Instead of striking while the government was relatively vulnerable, they were put off with one ploy or another until they were isolated and defenseless against the forces arraigned against them.

The IUC put this time to good use. On February 17th, it decided to widen the scope of its activity to meet any future threat by the Triple Alliance. It activated three committees on a national scale to arrange for the building up, storing, transporting and protecting of supplies. These committees were ordered to proceed with extreme caution and secrecy in order to "avoid provocative action which might precipitate a strike". ${ }^{4}$ This was only ten days before the much-publicized National Industrial Conference was due to begin. Any breach in the security surrounding the IUC's anti-strike activity would prove highly embarassing to the government and would ruin the Conference. But then, no one had much hope for the Conference anyway. Lloyd George gave some indication of how he felt in a letter to Bonar Law written on February 25th, in which he speculated that if the immediate labor disputes could not be settled, then "we shall have to fight the thing through. It may be a good thing, because Labour is getting unreasonable in some respects."5

1 Cab 23/10, War Cabinet 529 and 530, February 7 and 10, 1919.

2 Cab 27/59, meeting No 8, February 10, 1919.

3 For details from the miners' point of view, see R. Page Arnot, The Miners, II (London, 1953), pp. 182-202.

- Cab 27/59, meeting No 12, February 17, 1919. The IUC acted immediately following a Cabinet meeting on the same day, which had discussed the best way to meet foreign trade competition. It had come down hard in favor of decontrolling government regulation to provide for a "New, natural level of prices", cf. Johnson, pp. 365-72. This action it knew would probably provoke industrial unrest. It also knew that on February 27th the National Industrial Conference was due to start.

${ }^{5}$ Quoted in Johnson, pp. 372-3. 
This "unreasonableness" that so provoked Lloyd George was most obvious in the attitude of the railwaymen. While tensions had abated somewhat amongst the miners, negotiations with the railwaymen had broken down. ${ }^{1}$ By March 14th, the situation provoked the IUC into requesting a bill to allow the government to seize trade-union funds, arrest the leaders, and stop strike pay. ${ }^{2}$ The strike never came and hence the legislation was not needed at this time, but similar legislation would come up again. The crisis reached its peak during the last ten days in March. The railwaymen with the help of the leadership of the Triple Alliance finally forced sufficient concessions from the government to warrant the delay of its strike plans. ${ }^{3}$ The miners also backed off from their strike threat when the interim report of the Sankey Commission seemed to commit the government to a policy of nationalization. The third member of the Triple Alliance, the dockworkers' union, were engaged in negotiations which were, as Bonar Law put it, "progressing fruitfully". 4

Thus the government sailed through its most vulnerable period, and successfully delayed major confrontation until it had strengthened its strikebreaking capacities. The master strategist of this policy of delay was Bonar Law. Faced with negotiations with both the railwaymen and the miners at the end of March, Law successfully gave the impression of compromise and of yielding significant concessions to both, thus gaining what he needed most - time. Law and others were convinced that given time, the economy would revive, trade would increase, unemployment would decline, and the problems plaguing the nation would disappear. In the meantime they handled discontent on an ad hoc basis - with the assurance that if their optimistic predictions failed to materialize, the IUC would soon be able to handle any emergency.

Utilizing the time provided by Law's duplicity, the IUC continued to work on its plans and organization. One of the hardest problems it had to tackle was the development of an efficient transport system to ensure the flow of vital supplies during a rail strike. The difficulty was in the necessity for the government to be ready to step in immediately, for, unlike a coal strike, the effects of a rail strike could be felt right

1 For the railway negotiations, see Philip S. Bagwell, The Railwaymen (Iondon, 1963), pp. 370-81.

2 Cab 27/59, meeting No 15; also Bonar Law admitted in a letter to Lloyd George of March 21, 1919, that he "was prepared if a strike broke out to pass legislation empowering the Government to seize strike funds and arrest leaders", Bonar Law Papers 101.3.39, Beaverbrook Library.

3 Bagwell, pp. 378-80.

- Bonar Law to Lloyd George, March 21, 1919, Bonar Law Papers 101.3.31. 
away. Coal could easily be stockpiled along with other supplies, but that was of little use unless transport for these things was available. Men and machines had to be ready in advance if serious shortages were to be avoided. This posed serious security problems: how could vehicles be assembled, drivers be ready and trained, fuel and maintenance arranged for, all in secret?

Realizing that a completely adequate, alternate transport system could not be developed in absolute secrecy caused a split between the bold and the prudent on the IUC. The initial cause was a dispute over whether or not to print a public appeal for volunteers in the newspapers. Arguing for the bold, Robert Horne insisted that "either nothing should be done or all should be done"1. He then put forth a case for ignoring secrecy and getting on with the business at hand. Clifford Penny, the Minister of Food, and a consistent advocate of government neutrality towards labor, reminded the Minister of Labor that the policy he was advocating would ruin any possibility of his negotiations with the trade unions being of any use, and that such considerations should take precedence over the preparatory advantages that a public appeal for volunteers would bring. ${ }^{2}$ The matter was left up to the IUC Chairman, Shortt, who decided to print the notice on the grounds that "public notices can have a steadying effect on the community generally and also upon the railwaymen". 3

Thus it seemed that the government was becoming less concerned with its image of neutrality and more with its capacity to break strikes. Correspondingly, the workers were presented less as victims of economic circumstances and more as enemies of the state. Lloyd George furthered this attitude by telling the Cabinet in August, 1919, that it was important not to take any chances with labor, because "we should at once create an enemy within our borders, and one which would be better provided with dangerous weapons than Germany".4

But if the workers were equipped with dangerous weapons, the government's arsenal was even more impressive. With the food rationing machinery set up during the war still in existence ${ }^{5}$ and the

1 Cab 27/59, Minutes of the IUC, meeting No 28, August 14, 1919.

2 "Memo on Public Appeals For Volunteers", Cab 27/60, UC No 21.

3 Cab 27/59, meeting No 29.

4 Cab 23/15, War Cabinet 606A, August 5, 1919. Earlier he had put the same thought in slightly more dramatic terms in a letter to Tom Jones, writing that "Once the strike [by the Triple Alliance] begins, it is imperative that the state should win. Failure to do so would inevitably lead to a Soviet Republic so that we ought to have our plans well thought out." Lloyd George to Tom Jones, Lloyd George Papers F/23/4/36.

5 "Machinery for the Distribution and Rationing of Food", G149, War Series G. Cab 24/3. This machinery was expanded and made more efficient under 
government still in control of shipping, it had the power to deprive life. Lloyd George had already indicated that it meant to use these weapons. The IUC however had decided against it in March, 1919, on the grounds that, as Mr Shortt put it, "any scheme would be unworkable in which distinctions in the issue of food were drawn between strikers and non-strikers". ${ }^{1}$ But the issue was not dead and control of food and shipping was carefully maintained by a wary government for potential use against the miners, who, unlike the railwaymen, were conveniently isolated in villages apart from the rest of the population and, hence, could be more easily subjected to starvation.

On June 20th, the Sankey Commission came out with its full report, which pleased the miners since a majority of the commission members agreed on the necessity of nationalization. The government, however, was not pleased, and it bided its time before responding to the report. Tiring of the long wait, the Yorkshire miners went on strike in late July. Although there was some danger of the strike spreading, the IUC did not become directly involved. Instead Lloyd George sent his top troubleshooter Eric Geddes, to keep an eye on the strike and to take personal charge of government efforts to keep things under control. Geddes kept the IUC informed of the course of the strike, which ended in the middle of August, and is important insofar as it provided a case study for the government's preparations for the larger strikes to follow. For Geddes, the experience was a valuable lesson that would assist him in his later role as chairman of the government's strikebreaking organization during the coal strikes of 1920 and $1921 .^{2}$

With the end of the strike in Yorkshire, the government felt that its position had been sufficiently strengthened to allow it to declare its opposition to nationalization of the mines. The government had also met and broken a police strike in July, thus insuring the loyalty of its police. Abroad, things were also progressing more smoothly; Wilsonianism at Versailles had been deflected and the treaty was signed on June 26th. Communism seemed to be contained even if the Soviet Union resisted conquest. All told it had been a fruitful summer for the Lloyd George government. It was now ready to take the miners and the railwaymen with whomever they could muster for allies. Bonar

Lord Rhondda in 1918. Control of food prices became part of the Food Ministry's function in January of 1918, G180, Cab 24/4. The Food Ministry was revived on 19 July 1919 to import food in bulk in expectation of industrial strife. Control over shipping was maintained in order that the government could be assured of sufficient supplies in case of a general strike. Cf. Susan Armitage, pp. 33-6.

1 Cab 27/59, IUC meeting No 14, March 12, 1919.

${ }^{2} \mathrm{Cab} 27 / 50$ and 27/77. Contains Geddes's reports. 
Law announced the government's determination to fight any attempt to force a decision on "political questions", i.e., nationalization, with "all the resources at its disposal". 1

Lloyd George followed on August 18th with the announcement of his government's opposition to the majority decision of the Sankey commission with its recommendation of a form of nationalization. In its place he offered his own scheme of "amalgamation" of the mines and "amelioration" of the condition of the miners. Further, he announced, "the State should not purchase the mines, and certainly not run them". Caught off balance, the miners could only reflect agreement with the sentiment expressed by Vernon Hartshorn, ex-miner and a MP for South Wales, "We have been deceived, betrayed, duped." The miners' plight caught the sympathy of the TUC Parliamentary Committee, which ordered a special Congress to decide what to do about it. Confident that the entire working class would rally behind the miners, the Triple Alliance put off any action until after the TUC special congress which was scheduled for December. Delayed again, this time by well-meaning friends, the confrontation with the government now appeared inevitable to the miners. What they failed to understand was that each delay gave the government time to strengthen its position.

While the miners awaited the action of the TUC, the railwaymen grew increasingly restless with the fruitless negotiating of their executives. From March 30th to September 26th the NUR met with representatives of the railway companies and the government over forty times. In the summer of 1919, a surge from below brought on a series of unauthorized local and sectional strikes, which threatened to bring on a national strike regardless of the wishes of the NUR leadership. Negotiations in September faltered as it appeared that the government was backing away from the apparent commitments made by Bonar Law in March. Last minute talks by Lloyd George and NUR leader J. H. Thomas failed to produce any agreement. The Prime Minister, backed by an extensive strikebreaking organization displayed signs that he was eager to go into action. Eric Geddes, who had spent much of the year formulating plans for a new Ministry of Transportation, was waiting in the wings to take over the IUC. This caused Beatrice Webb to note in her diary that the strike was "desired if not engineered" by the Geddes brothers, who represented "the universal determination of the capitalists to reduce wages". ${ }^{3}$

1 The Times, August 6, 1919.

2 Hansard, August 18, 1919.

3 Beatrice Webb's Diaries, 1918-24, ed. by Margaret Cole (London, 1955), p. 167. 
Strike notices took effect on midnight of September 26th. At 5,00 p.m. on that day, the first meeting of the newly-ordained Strike Committee took place. ${ }^{1}$ The first order of business was to set up a subcommittee "to coordinate all existing arrangements in regard to transport by road". ${ }^{2}$ Eric Geddes, the newly installed chairman of the Strike Committee, had experimented with motor transport during the war. This experience combined with his civilian background as a manager of the Great Eastern Railway made him uniquely qualified for the task before him. As Director-General of Transportation in wartorn France, Geddes had often dealt with problems of logistics resulting from inoperative railways. ${ }^{3}$ Teams of drivers and lorries led by officers of the RASC had operated under Geddes's supervision. Some of these officers had already been returned from France to assist Geddes in planning the Transportation Ministry. In March, 1919, one hundred more of these officers were requested to aid, the IUC in organizing road transport in case of a strike. ${ }^{4}$ With the replacement of Shortt with Geddes as chief of the old IUC organization, these men were united with their old commander, and although the enemy was a quite different one, their approach to their task was the one they had learned while at war.

Besides this quite handy availability of military men, there were also large quantities of military equipment and vehicles ready for use; some of the vehicles had already seen service in the London tube strike. An IUC report indicated that 1,047 army lorries were available in March. This number was increased as men and machinery were returned from Europe. ${ }^{5}$ The advantage this gave the government was obvious, and no one appreciated it more than Arthur Henderson, who as Minister of Labour during the war had a firsthand acquaintance with the destructive potential of the government war machine. $\mathrm{He}$ referred to this in the course of the negotiations over the rail strike, commenting that he "realized that the government was better situated to meet a strike than they ever had been before, since the war machine could be put into operation against the men and could be used to smash the trade unions". 6

The immediate benefit that the government derived from the

1 The Strike Committee replaces the IUC in name, but the personnel and structure, with some additions and modification, remain the same. Cab 23/12, War Cabinet 626.

2 Cab 27/60, "Review of the Work of the Strike Committee", p. 1.

3 Sir Llewellyn Woodward, Great Britain and the War (London, 1967), pp. 256-8.

4 Cab 27/59, IUC meeting No 17, March 19, 1919.

5 Ibid.

- Cab 27/61, Minutes of Negotiation with Trade Union Leaders, October 2, 1919. 
military was that it could be mobilized immediately to set up a skeleton train service to take up some of the slack while civilian volunteers and transport were being readied. An IUC subcommittee had worked on this civilian force for six months. It had earmarked 40,000 private trucks and over 10,000 private cars for use in the event of a strike. Their owners had been notified to report to previously selected collection points upon the outbreak of the strike. Employment exchanges were used to recruit drivers as the need developed. ${ }^{1}$ Local authorities, private haulage companies, auto associations all were called upon to stand by to aid in this fight against those who would "strike against the life of the community" (as the government labeled it in its releases to the press). ${ }^{2}$ Both plans were set into operation and performed with "great smoothness and efficiency" (if we can believe the reports of the Strike Committee) for the duration of the strike, which lasted only seven days.

However, problems with fuel shortages, especially petrol and coal, were beginning to show up at the end of that time and surely would have become more severe if the strike had lasted any longer. Part of the shortage stemmed from the apathetic response of the general public to government requests that it revert to wartime restrictions on fuel consumption. Unlike Winston Churchill, who had reported to the Cabinet that he "could not see the distinction between the war and a civil emergency", ${ }^{3}$ much of the population felt that there was indeed a distinction, and it proved somewhat difficult to convince people it was their duty as British citizens to restrict their consumption in order to deprive the railwaymen of a raise in pay. Still patriotic appeals for volunteer drivers to man the government's system of transportation brought forth more "public spirited" souls than the government needed to drive its vehicles. Some of these drivers, those lacking the proper

${ }^{1}$ Cab 27/59, meeting No 17, March 19, 1919.

2 The Times, September 27, 1919.

3 The fact that the railwaymen and the dockworkers both won significant wage increases while the miners were left hanging has been used at times to show that Lloyd George was either weak or clever or some combination of the two. Evidence now would seem to indicate that he was neither, for the records of various strikebreaking committees show that the government was strong enough to fight but it chose at times to pay; a position that depends on cost analysis to determine strategy, something that every businessman does as a matter of course. Thus, Thomas and Bevin won increases during inflationary periods but the miners were held back during the depression of 1921 . The Triple Alliance could not hold together when faced with such strong economic facts. This is perhaps what Lloyd George meant in his comment to Lord Riddell after the strike, "Now we have detached the Railwaymen [from the Triple Alliance]." Lord Riddell's Intimate Diary, p. 131. 
"spirit", used the opportunity to make off with the vehicle they were charged to drive.

Throughout the strike, the government kept its ace in the hole, control of food, in abeyance. Although Lloyd George had called for the withholding of food from strikers, Geddes and the Food Ministry had vetoed the proposition as too difficult to administrate. Railwaymen were spread throughout the nation and, unlike miners, were difficult to segregate from the rest of the population. Notice that the policy was defeated because of administrative not humanitarian reasons.

Despite its problems, the Strike Committee had, by the end of the strike, proven it was indeed possible to avert the "lightning paralysis" (as Geddes called it) that had been a feature of past railway strikes. But if Geddes, the Strike Committee organization, and the military had performed well, the same could not be said of Lloyd George and the politicians. Their job had been to explain the strike and the government's strikebreaking efforts to the general public. To do this they used some heavy-handed red-baiting that proved grossly inappropriate against a union led by $\mathrm{J}$. H. Thomas, a man noted for his wily negotiating talents and conciliatory nature. So, when Lloyd George tried to blame the strike on a conspiracy "engineered by a small but active body of men who worked to exploit the labour organization of the country for subversive ends", his charge was effectively countered by Thomas and the NUR with the help of the Labour Research Department. They replied with full-page advertisements and film clips explaining the basis of the strike in the government's refusal to pay the men a decent wage. Lloyd George was forced to redirect his propaganda to come to terms with this argument, thus setting the stage for compromise. This process was hastened by direct pressure on the government by the threat of sympathetic strike action, particularly by the miners. A team of negotiators, headed by Arthur Henderson of the Labour Party, convinced the government of the wisdom of compromise and agreement was reached on October 5, 1919. The railwaymen got most of their wage demands while the government received some assurance that the Triple Alliance was from then on defunct. ${ }^{1}$

This was the last compromise of substance that the government would be forced to make. The Strike Committee had proven that it could, at least for a time, keep the vital flow of necessary goods in operation in spite of a national railway strike. To do this, it had depended to a substantial degree on the men who had been called up to fight World War I and soon would be demobilized. It had also depended on

1 Cab 23/9, War Cabinet 525, February 4, 1919. 
emergency wartime legislation as the legal basis for the actions of the Committee; this basis, the Defense of The Realm Act, was soon to expire. A new civilian-oriented organization had to be created and a different legality conferred upon it. To this end, Eric Geddes was put in charge of a third committee, the Supply and Transport Committee, which had much the same personnel as the first two, but whose emphasis was on adapting to civilian life. This Committee would be the most long-lived of the three and was activated to handle every industrial crisis of sufficient magnitude from 1920 to 1938, which was as far as its records were open at the time I was studying them. ${ }^{1}$

Its record revealed an unbroken string of successes, blurred occasionally with the stigma of political compromise. Its major victories were on Black Friday, April 15, 1921, and in the whimpering withdrawal of the TUC from the General Strike in 1926. It owed its victories largely to the lessons learned from the experience of its predecessors in 1919 , especially during the railway strike. To know that people would volunteer to break strikes in large numbers and that motor transport could keep the country supplied with essential goods if the railways were shut down gave the government a new sense of confidence. This meant that it was feasible to break even the largest of strikes without the use of military force. Above all, there was a new sensitivity to the value of acceptable propaganda. No more blundering red-baiting - that was the sport of amateurs --, the new propaganda would be designed with broader appeal to more honorable British traditions like defense of the constitution. The effect, however, would be the same - to defeat the British workers, to deplete trade-union treasuries, and to ensure the security of British capital.

As the government's secret weapon, the Supply and Transport Committee's existence was felt and acknowledged by the trade unions; it was even activated by the Labour Party in 1924 during its short reign, but its full strength and the details of its organization remained until recently a mystery to all but the men who served it so well. It is to these men, some of them famous like Eric Geddes and John Anderson, but most of them unsung civil servants, that British capital owes an enormous debt, for they were responsible for preserving the system which kept the basic exploitative relationship between capital and labor intact. Throughout the period from 1919 to 1939, these civil servants met periodically to review and modernize the strikebreaking capacity of the British government. Politics made little difference;

1 The history of the Committee is given in detail in my unpublished dissertation "The Supply and Transport Committee: A Study of the British Government's Method of Handling Emergencies Stemming from Industrial Disputes" (University of Wisconsin, 1970). 
they continued to work and plan through the coalition government of Lloyd George, the Conservative governments of Bonar Law and Stanley Baldwin, and the Labour Government of Ramsay MacDonald. It is a serious and sad commentary on the class consciousness of the Labour Party that its leaders considered loyalty to the government above loyalty to class, and never revealed the details of the strikebreaking machinery to the trade union leaders even in the face of the General Strike. In a sense it was suicidal, for the defeat of the trade unions ultimately meant a decrease in their base of power. It took a depression and another world war to bring the unions and the Labour Party back together. But this time it was a unity based on social welfare and wrapped in anti-communism; the old spirit of socialism and workers' control was gone, smothered by the counter-revolutionary blanket of bureaucratic civil service. 